\title{
Penerapan Sistem Pengendalian Keselamatan dan Kesehatan Kerja pada Pelaksanaan Proyek Konstruksi di Kota Padang
}

\author{
Jajang Atmaja'), Enita Suardi²), Monika Natalia ${ }^{3)}$, Zulfira Mirani ${ }^{4)}$, Marta Popi Alpina ${ }^{5)}$ \\ 1), 2), 3), 4) Jurusan Teknik Sipil Politeknik Negeri Padang, Kampus Politeknik Limau Manis Padang \\ 5) Mahasiswa Jurusan Teknik Sipil Politeknik Negeri Padang,Kampus Limau Manis \\ email .jajang.atmaja@gmail.com, enitasuardi@gmail.com, monikanatalia75@gmail.com, \\ raninawaf@gmail.com, martapopibrs@gmail.com
}

\begin{abstract}
Abstrak
Keselamatan dan Kesehatan Kerja merupakan masalah yang kompleks pada suatu proyek konstruksi. Kecelakaan kerja dan penyakit akibat kerja umumnya disebabkan oleh faktor manajemen, disamping faktor manusia dan teknis. Tingkat pengetahuan, pemahaman, perilaku, kesadaran, sikap dan tindakan masyarakat pekerja dalam upaya penanggulangan masalah keselamatan kerja masih sangat rendah dan belum ditempatkan sebagai suatu kebutuhan pokok bagi peningkatan kesejahteraan secara menyeluruh termasuk peningkatan produktivitas kerja. Sistem Pengendalian Keselamatan dan Kesehatan Kerja bertujuan mencegah, mengurangi, bahkan menihilkan risiko kecelakaan kerja (zero accident). Penerapan konsep ini tidak boleh dianggap sebagai upaya pencegahan kecelakaan kerja dan penyakit akibat kerja yang menghabiskan banyak biaya (cost) perusahaan, melainkan harus dianggap sebagai bentuk investasi jangka panjang yang memberi keuntungan yang berlimpah pada masa yang akan datang. Penelitian dilakukan pada proyek pembangunan Kantor Pengadilan Tinggi Negeri Kelas 1A dan Rumah sakit Hermina Padang. Responden dalam penelitian ini adalah 30 responden yaitu pekerja yang terlibat dalam proyek. Pengujian dilakuan dengan menggunakan uji validitas, uji reliabilitas, uji korelasi dan analisis deskriptif. Penelitian ini dilakukan dengan cara menyebar kuesioner dan melakukan wawancara dengan kontraktor, dari kuesioner yang disebar menggunakan variable: pekerja, Fasilitas Penunjang Keseharian Untuk Pekerja, Fasilitas Penunjang di Lokasi Proyek dan Penyebaran Informasi K3(Keselamatan dan Kesehatan Kerja ).
\end{abstract}

Kata kunci: Penerapan sistem pengendalian K3, alat pelindung diri, pekerja, perusahaan 


\section{PENDAHULUAN}

Indonesia merupakan salah satu negara berkembang di mana banyak sekali pembangunan yang sedang dilaksanakan. Pembangunan yang cukup signifikan terjadi pada pembangunan di bidang konstruksi. Beberapa proyek konstruksi di Indonesia banyak terjadi di kota besar salah satunya kota Padang Dalam pengerjaan proyek selain memperhatikan ketepatan waktu, mutu, dan biaya, perusahaan konstruksi perlu juga memperhatikan keselamatan dan kesehatan kerja di proyek.

Keselamatan dan Kesehatan Kerja merupakan masalah yang kompleks pada suatu proyek konstruksi. Kecelakaan kerja dan penyakit akibat kerja umumnya disebabkan oleh faktor manajemen, disamping faktor manusia dan teknis. Tingkat pengetahuan, pemahaman, perilaku, kesadaran, sikap dan tindakan masyarakat pekerja dalam upaya penanggulangan masalah keselamatan kerja masih sangat rendah dan belum ditempatkan sebagai suatu kebutuhan pokok bagi peningkatan kesejahteraan secara menyeluruh termasuk peningkatan produktivitas kerja.

Sistem Pengendalian Keselamatan dan Kesehatan Kerja bertujuan mencegah, mengurangi, bahkan menihilkan risiko kecelakaan kerja (zero accident). Penerapan konsep ini tidak boleh dianggap sebagai upaya pencegahan kecelakaan kerja dan penyakit akibat kerja yang menghabiskan banyak biaya (cost) perusahaan, melainkan harus dianggap sebagai bentuk investasi jangka panjang yang memberi keuntungan yang berlimpah pada masa yang akan datang.
Setiap orang membutuhkan pekerjaan untuk memenuhi kebutuan hidupnya. Dalam bekerja Keselamatan dan Kesehatan Kerja (K3) merupakan faktor yang sangat penting untuk diperhatikan karena seseorang yang mengalami sakit atau kecelakaan dalam bekerja akan berdampak pada diri, keluarga dan lingkungannya.

Berdasarkan latar belakang di atas penulis ingin meninjau proyek yang berapa di Kota Padang yang sedang pelaksanaan pembangunan yang berada di tepi laut. Mengingat risiko akan terjadinya kecelakaan kerja sangat tinggi karena dekat dengan laut, kemungkinan angin laut berisiko sangat tinggi untuk pekerjaan di ketinggian. Dan ada juga pekerjaan ditempat pemukiman yang padat penduduk supaya pelaksanaan proyek tidak menggaggu dari aktifitas masyarakat di sekitar proyek.

\section{TINJAUAN PUSTAKA}

Menurut Peraturan Pemerintah No. Per. 50/PP/2012 Pasal 3: Setiap perusahaan yang mempekerjakan tenaga kerja sebanyak 100 orang atau lebih dan mengandung potensi bahaya yang dapat ditimbulkan oleh karakteristik proses atau bahan produksi yang dapat mengakibatkan kecelakaan kerja, seperti peledakan, kebakaran, pencemaran dan penyakit akibat kerja wajib menerapkan Sistem Manajemen K3.

Tujuan utama dilakukan Pelaksanaan Sistem Pengendalian K3 diharapakan mampu membentuk suatu Sistem Keselamatan dan Kesehatan Kerja di tempat kerja melalui integrasi dengan berbagai unsur manajemen, tenaga kerja, kondisi, dan lingkungan kerja dalam rangka mencegah dan mengurangi kecelakaan kerja dan penyakit akibat 
kerja. Menciptakan tempat kerja yang aman dari kejadian kebakaran, peledakan dan kerusakan yang pada akhirnya akan melindungi investasi perusahaan serta menciptakan kondisi tempat kerja yang sehat. Selain itu, pelaksanaan penerapan K3 juga diharapkan meningkatkan efisisensi dan produtivitas kerja. Hal tersebut dapat terwujud sebab perusahaan dapat menghemat biaya kompensasi akibat sakit atau kecelakaan kerja (Kementrian Ketenaga kerjaan Republik Indonesia, 1996).

Keselamatan dan kesehatan kerja merupakan upaya preventif yang kegiatan utamanya adalah mengidentifikasi, mensubtitusi, mengeliminasi, mengevaluasi, dan mengendalikan risiko bahaya. Identifikasi bahaya dapat dilakukan dengan jalan inspeksi, survey dan monitoring tempat kerja. Untuk mengidentifikasi masalah $\mathrm{K} 3$, baik manajemen maupun teknik, maka perlu dilakukan audit K3.

Tujuan dan sasaran Sistem Pengendalian K3 adalah menciptakan suatu sistem keselamatan dan kesehatan kerja di tempat kerja dengan melibatkan unsur manajemen, tenaga kerja, kondisi dan lingkungan kerja yang terintegrasi dalam rangka mencegah dan mengurangi kecelakaan dan penyakit akibat kerja serta terciptanya tempat kerja yang aman, efisien, dan produktif.

Manfaat penerapan Sistem Manajemen Keselamatan dan Kesehatan Kerja (SMK3) bagi perusahaan menurut Tarwaka (2008) adalah:

1. Pihak manajemen dapat mengetahui kelemahan-kelemahan unsur sistem operasional sebelum timbul gangguan operasional, kecelakaan, insiden dan kerugian-kerugian lainnya.

2. Dapat diketahui gambaran secara jelas dan lengkap tentang kinerja K3 di perusahaan.

3. Dapat meningkatkan pemenuhan terhadap peraturan perundangan bidang $\mathrm{K} 3$.

4. Dapat meningkatkan pengetahuan, ketrampilan dan kesadaran tentang $\mathrm{K} 3$,khususnya bagi karyawan yang terlibat dalam pelaksanaan audit.

5. Dapat meningkatkan produktivitas kerja.

\section{Manajemen Sumber Daya Manusia}

Manajemen sumber daya manusia dapat diartikan sebagai kegiatan perencanaan, pengorganisasian, pengarahan dan pengendalian atas pengadaan tenaga kerja, pengembangan, kompensasi, integrasi, pemeliharaan dan pemutusan hubungan kerja dengan sumber daya manusia untuk mencapai sasaran perorangan, organisasi, dan masyarakat (Flippo, 1997). Sedangkan menurut Herry Simanora (2004), manajemen sumber daya manusia adalah pendayagunaan, pengembangaan, penilaian,pemberian balas jasa, dan pengolahan individu anggota organisasi atau kelompok karyawan.

Adapun, tujuan utama dari manajemen sumber daya manusia adalah untuk meningkatkan konstribusi sumber daya manusia (karyawan) terhadap organisasi. Hal ini dapat di pahami bahwa semua kegiatan organisasi dalam mencapai tujuannya tergantung sumber daya manusia mengmengelolah organisasi tersebut. Oleh karena itu, organisasi harus mengelolah dan mendayagunakan SDM atau karyawan yang 
dimilikinya dengan baik sehingga dapat membantu mencapai tujuan organisasi yang telah di tentukan.

\section{Pengertian Keselamatan dan Kesehatan Kerja (K3)}

Menurut Mangkunegara (2002: 163) Keselamatan dan kesehatan kerja adalah suatu pemikiran dan upaya untuk menjamin keutuhan dan kesempurnaan baik jasmaniah maupun rohaniah tenaga kerja pada khususnya, dan manusia pada umumnya, hasil karya dan budaya untuk menuju masyarakat adil dan makmur.

Adapun sasaran keselamatan kerja secara terinci adalah:

1. Mencegah terjadinya kecelakaan di tempat kerja

2. Mencegah timbulnya penyakit akibat kerja

3. Mencegah/mengurangi kematian akibat kerja

4. Mencegah atau mengurangi cacat tetap

5. Mengamankan material, konstruksi, pemakaian, pemeliharaan

bangunan-bangunan, alat-alat kerja, mesin-mesin, pesawat-pesawat, instalasiinstalasi.

6. Meningkatkan produktivitas kerja tanpa memeras tenaga kerja dan menjamin kehidupan produktifnya

7. Mencegah pemborosan tenaga kerja, modal, alat dan sumber-sumber produksi lainnya sewaktu kerja

8. Menjamin tempat kerja yang sehat, bersih, nyaman, dan aman.

9. Memperlancar, meningkatkan dan mengamankan produksi, industri serta pembangunan.

\section{Faktor - Faktor yang mendorong Penerapan Keselamatan dan Kesehatan Kerja (K3)}

Banyak kalangan industry menganggap $\mathrm{K} 3$ sudah menjadi kebutuhan yang sangat penting. Tanpa adanya penerapan K3 di lingkungan kerja maka kemungkinan terjadinya kecelakaan kerja sangat besar. Menurut seorang ahli keselamatan kerja, Willy Hammer mengatakan bahwa ada tiga alasan pokok mengapa program $\mathrm{K} 3$ perlu di laksanakan yaitu berdasarkan perikemanusiaan, UU atau hukum dan alasan ekonomi. Kemudian, Goudzali juga mengungkapkan hal yang serupa mengenai foktot - faktor pentingnya penerapan $\mathrm{K} 3$, antara lain :

- Kemanusiaan. Para karyawan merupakan manusia biasa yang bukan semata mata sebagai alat rodukdi, tetai adalah sosok manusia yang merupakan asset perusahaan. Dengan demikian, setiap manusia perlu mendapat perlindungan dari segala ancaman dan bahaya yang selalu mengintaai di sekitarya.

- Peraturaan Pemerintah. Suatu perusahaan, apapun jenis usaha yang dilakukan, bertujuan agar produknya itu dapat dipakai atau digunakan oleh masyarakat dan keberadaan perusahaan di tengah masyarakat tersebut mempunyai hubugan sehingga keberadaannya itu diatur melalui berbagai mekanisme peraturan perundang undangan.

- Ekonomi factor ekonomi juga merupakan pendorong diberlakukannya pemeliharaan K3 dalam suatu perusahaan. Hal in dapat 
dipahami bahwa suatu perusahaan dalam operasinya akan selalu bergerak menurut pertimbangan ekonomis yaitu mencari keuntungan. Dengan melakukan pemeliharaan K3 secara terus menerus. Berarti perusahaan harus mengelurkan akan lebih besar lagi apabila terjadi kecelakaan kerja. Pemeliharaan K3 ditujukan untuk mencegah terjadinya kecelakaan kerja.

Faktor - Faktor Penyebab Kecelakaan Kerja. Menurut International Labour Organization (ILO), terdapat 3 faktor yang menyebabkan kecelakaan kerja yaitu :

* Faktor peralatan Teknis, biasanya menyangkut masalah keburukan pabrik, peralatan yang digunakan, mesin mesin yang sudah tidak layak pakai.

* Faktor lingkungan kerja, meliputi lingkunan fisik tempat kerja maupun lingkungan sosial psikologis yang lebih luas.

* Faktor Manusia

Maksudnya tenaga kerja tidak mengetahui tata cara yang aman atau perbuatan yang berbahaya: tidak sanggup memenuhi persyaratan kerja sehingga terjadi tindakan di bawah standar, mengetahui seluruh peraturan dan persyaratan kerja tetepi tidak mematuhinya.

Tujuan Penerapan sistem pengendalian Keselamatan dan Kesehatan Kerja.
Tujuan utama dari Penerapan sistem Pengendalian keselamtan dan kesehatan kerja adalah mewujudkan masyarakat dan lingkungan kerja yang aman, sehat dan sejahtera. Tujuan keselamatan dan kesehatan kerja menurut Mangkunegara, sebagi berikut :

- Agar setiap pegawai mendapat jaminan K3 baik secara fisik, social dan psikologi

- Agar setiap perlengkapan dan peralatan kerja digunakan sebaik -baiknya dan seefektif mungkin

- Agar semua hasil produksi dipelihara keamanannya

- Ada jaaminan atas pemeliharaan dan peningkatan kesehatan gizi pegawai

- Agar meningkatkan kegairahan, keserasian kerja dan partisipasi kerja

- Agar terhindar dari gangguan kesehatan yang disebabkan oleh lingkungan atau kondisi kerja

- Agar setiap pegawai merasa aman dan terlindungi dalam bekerja.

\section{Syarat - syarat Keselamat dan Kesehatan Kerja} (K3).

a. Pembinaan K3

Kegiatan sosialisasi K3 bagi seluruh pegawai dari seluruh tingkat jabatan, yang dapat berupa penyuluhan, pelatihan, kursus, pemasangan poster keselamatan kerja, pemasangan rambu rambu atau tanda peringatan bahaya, pemasangan UU keselamatan kerja di tempat kerja. dll (Sendjum, (2001). 
b. Kondisi fisik tempat kerja

Tempat keerja adalah setiap ruangan atau lapangan, tertutup atau terbuka bergerak atau tetap diaman tenaga kerja bekerja, untuk keperluan atau suatu usaha dan dimana terdapat sumber atau sumber - sember bahaya kerja. (Kansil, 2001). Kebersihan perawatan tempat kerja, melainkan juga faktor fisik lainnya seperti suara, suhu penerangan, dan penyediaan alat pemadaman api yang memadai.

Kondisi fisik tempat kerja yang baik akan meminimalisir resiko terjadinya kecelakaan kerja yang diakibatkan oleh kondisi tidak aman, dan dampaknya kepada pekerja adalaah berkurangnya ketegangan - ktegangan (pemisahan sosial, rasaa bosan, letih, dan tidak diperhatikan) yang dirasakan oleh pekerja (Gerry Desler, 1998:137).

\section{c. Proses kerja}

Merupakan selurh kegiatan yang dilaksanakan dalam bekerja, dimulai dari kegiatan paling aawal hingga akhir. Proses kerja yang sesuai akan membekali pekerjaan dengan pengetahuan lengkap mengebai pekerjaannya dan myngurangi stress dan konsekuensi lainnya akibat stress dikalngan pekerja.

d. Alat - alat pelindung diri (APD) bagi Tenaga Kerja

Yang dimaksud dengan alat pelindung diri adalah "Seperangkaat alat yang digunakan tenaga kerja untuk melindungi sabagaian atau seluruh tubuhnya dari pengunaan potensi bahaya atau kecelakaan kerja (Sugeng Budionao dan Jusuf 329). Penggunaan alat pelindung diri dapat berbeda - neda. Tergangtung jenis - jenis pekerjaan yang dilakukan. APD yang bisa digunakan :

- Helm pengaman ( safety helment)

- Alat pelindung pendengaran (ear protection)

- Alat pelindung mata (googles)

- Alat pelindung pernapasan

- Pelindung muka

- Pelindung tangan (glover)

- Pelindung kaki (safety shoes)

- Pelayanan dan fasilitas kesehatan

Hal ini memegang peranan penting dalam menjaga K3 karena sejumlah malasah yang berkaitan dengan kesehatan akan dapar merusak kinerja pegawai. Oleh karena itu, adanya perhaatian atas haal ini menjadi halyang penting. Pelayanan dan fasilitas kesehatan yang dimaksud antara lain tersedianya tenaga kerja mesid ahli beserta obat obat - obatan daan saran medis dalam menghadapi kecelakaan kerja maupun penyakit akibat kerja. (Achmat Ramdahi,2012)

\section{METODE PENELITIAN}

Dalam penelitian ini metodologi yang digunaakan menggambarkan tentang cara pengumpulan data yang diperlukan guna menjawab permasalahaan yang ada dan merupakam hal yang penting untuk menentukan secara teoritis teknik operasional yang dipakai sebagai penggangan dalam mengabil langkah langkah penelitian. Pemilihan metode penelitian adalah sangat penting dalam membantu mengumpulkaan dan mengidentifikasi semua variable yang relevan, mekanisme dan kualitas yang dominan mempengaruhi penelitian. 
Untuk mencapai tujuan suatu penelitian diperlukan suatu rencana penelitian yang didalamnya memuat proses perencanaan dan pelaksanaan penelitian yang sistematis, terorganisir, berjalan secara efektif dan efisien serta tepat sasaran. Proses metode penelitian merupakan gabungan dari beberapa tahap.

\section{Data Penelitian}

Data yang akan diteliti dan dianalisis dalam penelitian ini terdiri dari 2 (dua) data, yaitu data primer dan data skunder:

1. Data primer

Data primer didapat dengan melakukan studi lapangan. Studi lapangan dilakukan dengan cara mengumpulkan data dengan menyebarkan kuesioner kepada kontraktorkontraktor yang terdaftar sebagai anggota GAPENSI kota Padang

2. Data sekunder

Merupakan data atau informasi yang diperoleh dari studi literatur, seperti bukubuku, jurnal, penelitian-penelitian yang berkaitan sebelumnya, dan juga disebut data yang sudah diolah, meliputi:

a. Data yang digunakan sebagai landasan teori untuk penelitian ini diperoleh dari buku-buku, jurnal, makalah dan lainlain.

b. Data untuk penelitian juga diambil dari penelitian sebelumnya.

\section{ANALISA DAN PEMBAHASAN}

Lokasi pengambilan data dilakukan pada proyek Kantor Pengadilan Tinggi Negeri Kelas $1 \mathrm{~A}$ dan Rumah Sakit Hermina,Padang.

\section{Karakteristik Responden Berdasarkan Umur.}

Tabel 1. Umur

\begin{tabular}{||l|l|l|l||}
\hline \hline No & Umur & Jumlah & Persentase \\
\hline 1 & $17-20$ tahun & 1 & $3,3 \%$ \\
\hline 2 & $\begin{array}{l}21-30 \\
\text { tahun }\end{array}$ & 8 & $26,7 \%$ \\
\hline 3 & $\begin{array}{l}31-40 \\
\text { tahun }\end{array}$ & 21 & $70,0 \%$ \\
\hline & Total & 30 & $100 \%$ \\
\hline
\end{tabular}

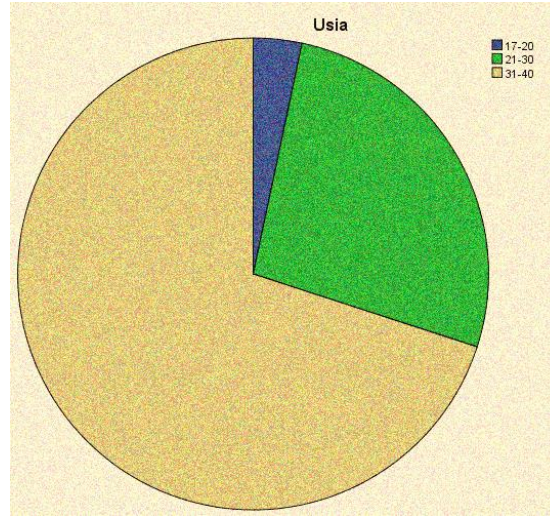

Dari tabel 1 dan gambar 1 dapat dijelaskan umur dari responden didominasi oleh pekerja yang berumur $17-20$ sebanyak 3,3\% tahun diikuti oleh pekerja yang berumur 21-30 tahun 26,7 \%, 31-40 tahun $70,0 \%$.

Tabel 2. Jenis Kelamin

\begin{tabular}{||l|l|l|l||}
\hline No & $\begin{array}{l}\text { Jenis } \\
\text { Kelamin }\end{array}$ & Jumlah & Persentase \\
\hline 1 & $\begin{array}{l}\text { Laki } \\
\text { laki }\end{array}$ & 30 & $100 \%$ \\
\hline & Total & 30 & $100 \%$ \\
\hline
\end{tabular}




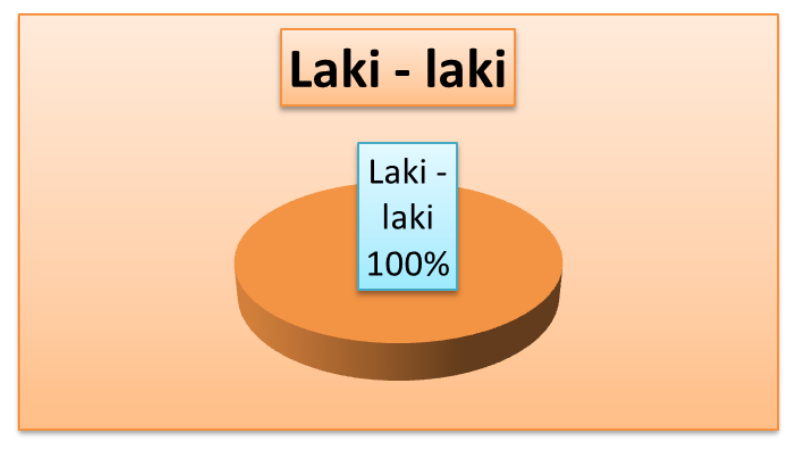

Dari tabel 2 dan gambar 2 dapat dijelaskan jenis kelammin dari responden didominasi laki laki.

Tabel 5. Hasil Pengujian Validitas Variabel Penyebab Pekerja (X1)

Berdasarkan tabel 4.5 di atas menunjukkan bahwa setiap pernyataan pada variabel penyebab pekerja adalah valid. Hal ini dikarenakan rhitung $>$ rtabel.

Tabel 10. Hasil Pengujian Reliabilitas Perlukah adanya pelatihan tentang pentingnya $\mathrm{K} 3$ di dalam suatu proyek.

\section{Reliability Statistics}

\begin{tabular}{|l|l|}
\hline $\begin{array}{l}\text { Cronbach's } \\
\text { Alpha }\end{array}$ & $\mathrm{N}$ of Items \\
\hline .908 & $\mathrm{X} 1.1$ \\
\hline
\end{tabular}

Dari hasil pengujian reliabilitas untuk variabel karakteristik construction site dari nilai cronbach's alpha hitung diperoleh sebesar 0,908 artinya dapat dikatakan bahwa untuk variabel karakteristik construction site reliabel karena nilai alpha antara 0,61 - 0,80 sesuai dengan Tabel 4.10. Dapat disimpulkan konsistensi dari pertanyaan- pertanyaan untuk sub-variabel Perlukah adanya pelatihan tentang pentingnya $\mathrm{K} 3$ di dalam suatu proyek sangat konsisten dan sangat tepat.

Dari hasil wawancara yang dilakukan untuk melengkapi hasil penelitian ini, penulis mengajukan 16 pertanyaan yang berkaitan dengan penerapan sistem pengendalian keselamatan dan kesehatan kerja pada pelaksanaan proyek konstruksi di kota Padang. Berikut hasil dari wawancara yang telah dilakukan kepada Ahli K3 pada proyek kantor pengadilan tinggi negeri:

1. Responden menanggapi pertanyaan taukah perusahaan tentang Undang undang yang mengatur tentang K3. Responden menanggapi tau dan mengerti tentang undang-undang yang mengatur K3 karena setiap tenaga ahli K3 mendapatkan pelatihan dan pengetahuan tentang undang-undang $\mathrm{K} 3$ yang berlaku, jadi untuk setiap tenaga untuk bekerja pada perusahaan harus paham dan mengerti tentang undang-undang $\mathrm{K} 3$.

2. Responden menanggapi pertanyaan bagaimana upaya perusaan untuk memenuhi standar K3 di proyek ini. Responden menanggapi yaitu dengan menerapkan semua aturan-aturan dan undang-undang yang mengatur tentang K3. Untuk setiap pelaksanaan proyek didalam undang-undang sudah diatur bahwa perusahaan harus mengutamakan keselamatan dan kesehatan dari pekerjanya baik itu dalam skala besar maupun kecil. 
3. Responden menanggapi pertanyaan apa alasan perusahaan menerapkan sistem pengendalian $\mathrm{K} 3$ sebagai upaya untuk meminimalkan kecelakaan kerja (zero accident) dan menjamin setiap kesehatan pekerja di dalam proyek dan juga tercantum pada undang-undang bahwa setiap pekerjaan proyek perusahaan wajib memiliki tenaga ahli K3 sebagai syarat memenangkan tender

4. Responden menanggapi pertanyaan Seberapa penting penerapan sistem pengendalian $\mathrm{K} 3$ responden menanggapi pada perusahaan sangat penting. Hal ini dikarena untuk menjamin keselamatan dan kesehatan pekerja

5. Responden menanggapi pertanyaan Apakah Perusahaan memiliki peraturan yang jelas mengenai prosedur keselamatan kerja. responden menanggapi tentu ada, untuk pedoman peraturan prosedur keselamatan telah diatur didalam undang-undang yang berlaku. Setiap aturan-aturan yang yang tertuang dalam undang-undang harus dipatuh.

6. Responden menanggapi pertanyaan Bagaimana peranan pemerintah terhadap sistem pengendalian $\mathrm{K} 3$ di industri konstruksi yang ada di Kota padang. Responden menanggapi peranan pemerintah dapat dilihat untuk aturan keselamatan dan kesehataan kerja telah diatur dalam perda pemerintah setempat jadi setiap aturan kita harus patuhi agar setiap pelaksanaan proyek dapat berjalan dengan baik.

7. Responden menanggapi pertanyaan Setujukah bahwa penerapan K3 yang baik akan memberikan rasa aman dan nyaman pada pekerja dalam pelaksanaan proyek konstruksi. Responden menanggapi setuju, karena pada hakekatnya aturan K3 adalah untuk menjamin keselamatan dan kesehatan kerja.

8. Responden menanggapi pertanyaan Apakah perusahaan anda mengikut sertakan para pekerja pada pelatihan mengenai prosedur keselamatan kerja.Responden menaggapi. Tidak, kalau untuk pelatihan kami tidak menyediakannya karena itu tanggung jawab dari mandor masing-masing tapi kalau untuk informasi dan penyuluhan K3 sudah dilakukan karena itu ada agendanya setiap bulan.

9. Responden menanggapi pertanyaan Bagaimana mengenai pelaksanaan sistem manajemen keselamatan dan kesehatan kerja (SMK3) pada proyek konstruksi di Indonesia pada umumnya dan khususnya di Kota Padang. Responden menanggapi. Pelaksanaan sistem keselamatan dan kesehatan kerja, sudah dilakuakan dengan baik dan sesuai dengan aturan-aturan yang berlaku, karena dengan adanya peraturan Mentri Tenaga Kerja setiap perusahaan yang memperkerjakan tenaga kerja sebanyak ratusan orang atau lebih dan atau yang mengandung poteksi 
bahaya wajib menggunakan SNK3 pada perusahaan tersebut.

10. Responden menanggapi pertanyaan Seberapa pentingnya Penerapan sistem Pengendalian K3 pada sebuah proyek konstruksi terhadap pencegahan kecelakaan kerja. Responden berpendapat adanya penerapan sistem pengendalian K3 sangan penting di sebuah proyek konstruksi terhadap pencegahan kecelakaan kerja.

11. Responden menanggapi pertanyaan Bagaimana tindakan perusahaan apabila terjadi kecelakaan kerja baik itu untuk kecelakaan berat atau sedang. Responden menanggapi. Pertama kalau terjadi kecelakaan berat langkah pertama adalah mengamankan kondisi agar pekerja tidak terpengaruh dengan apa yang sedang terjadi, lalu kita akan melihat kondisi korban lalu akan dibawake rumah sakit terdekat untuk pertolongan ke korban dan kami akan mengevaluasi mengenai keselamatan yang lebih baik lagi sehingga kecelakaan tidak terjadi lagi.

12. Responden menanggapi pertanyaan Apa yang dilakukan perusahan anda apabila tenaga kerja melanggar aturan K3. Responden menanggapi, kami akan menekan disiplin mengenai keselamatan dan kesehatan kerja yang telah disepakati bersama, demi keselamatan pekerja dan menjaga nama perusahaan.

13. Responden menanggapi pertanyaan Apakah penerapan sistem K3 di proyek ini sudah optimal. Responden menanggapi, kami rasa sistem K3 untuk proyek ini sudah optimal dan sesuai denganaturan yang berlaku.

14. Responden menanggapi pertanyaan Areal mana yang paling rawan terjadinya kecelakaan kerja. responden menanggapi, untuk setiap pelaksanaan proyek merupakan tempat yang berbahaya karena pekerjaan proyek adalah pekerjaan berat dank eras.

15. Responden menanggapi pertanyaan Apakah Pengendalian K3 berdampak positif bagi perusahaan. Responden penerapan K3 oleh perusahaan berdampak sangan positif. Adapun alasan penerapan K3 oleh perusahan yaitu dapat menimalisir angka kecelakaan kerja dan penyakit akibat kecelakaan kerja, mungurangi biaya untuk kecelakaaan kerja tersebut dan berpengaruh pada nama baik perusahaan.

16. Responden menanggapi pertanyaan Bagaimana upaya perusahaan untuk menimalisir kecelakaan kerja di proyek ini. Responden menanggapi, mematuhi semua aturan tentang $\mathrm{K} 3$ yang telah berlaku seperti membuat papan peringatan, petunjuk arah, dan rutin memantau keadaaan di lokasi proyek apabila ada pekerjaan yang melanggar aturan maka akan ditegur bahkan mendapat sanksi. 


\section{KESIMPULAN DAN SARAN}

\section{Kesimpulan}

1. Pengendalian risiko keselamatan dan kesehatan kerja proyek di kota padang adalah dengan cara mematuhi dan memenuhi semua aturan yang berlaku tentang keselamatan dan kesehatan kerja baik telah diatur didalam undang-undang maupun peraturan dari pemerintah. Mengendalikan risiko harus mengenal terlebih dahulu risiko-risiko yang akan terjadi nantinya sehingga risiko yang akan terjadi akan dapat diminimalisir atau bahkan hilang. Upaya pengendalian pengendalian risiko keselamatan dan kesehatan kerja di kota Padang adalah

a. Mengidentifikasi risiko yang akan terjadi

b. Merumuskan dampak yang akan terjadi

c. Menganalisa penyabab dari risikorisiko yang akan terjadi

d. Memutuskan penanganan dari risiko-risiko yang akan terjadi nantinya

2. Kelengkapan terhadap pelindung tubuh dan areal proyek sangat dibutuhkan baik itu ketersediaan alat pelindung diri, pemadam api ringan dan rambu-rambu peringatan sangat penting pada lokasi proyek, karena lokasi proyek adalah tempat yang sangat berisiko terjadinya kecelakaan kerja. kelengkapan tersebut sudah diatur didalam undang-undang sehingga apabila tidak memenuhi dari yang disyaratkan didalam undang-undang maka proyek maupun kontraktor dapat dihentikan.
Sejauh ini proyek-proyek di kota Padang sudah lebih baik dari sebelumnya dalam menjamin keselamatan tenaga kerja dan lokasi proyek. Kontraktor-kontraktor di kota Padang sudah menunjukan profesionalan mereka dalam keseriusan mengenai keselamatan dan kesehatan kerja tetapi masih ada juga kontraktor-kontraktor yang nakal yang tidak memperhatiakan keselamatan dari tenaga kerja. perlunya keterlibatan pihak-piihak lain selama pelaksanaan proyek, dan juga bagi owner harus bertindak keras apa bila kontraktor tidak memenuhi semua aturan tentang keselamtan dan kesehatan kerja. Pada proyek konstruksi gedung di kota padang, dapat di simpulkan penerapan sistem pengendalian K3 di Kota Padang saat minim, karena banyak pekerja yang berpendapat bahwa keselamatan kerja tidak terlalu penting, dan juga kesadaran dari pekerja tentang bahayanya kecelakaan kerja sangan kurang dan penerapan dari perusahaan masih kurang ketat.

\section{Saran}

Adapun saran yang didapat dari penelitian ini adalah:

1. Bagi kontraktor pengendalian setiap risiko yang akan terjadi perlu diperhatikan agar tidak menghambat pelaksanaan proyek. Pengendalian risiko keselamatan dan kesehatan kerja dapat diminimalisir bahkan dihilangkan dengan cara mengidentifikasi risiko-risiko yang akan terjadi sehingga dapat ditangani dengan cepat.Perlunya keterlibatan 

pihak-pihak lain dalam mengontrol
keselamatan dan kesehatan kerja agar
pelaksanaan proyek minim dari resiko kecelakaan. Sikap tegas dari owner dan konsultan juga sangat diperlukan untuk menegakan tentang keselamatan dan kesehatan kerja yang telah diatur didalam undang-undang. Perlu adanya sosialisasi penerapan program keselamatan dan kesehatan kerja diantaranya dengan cara pendidikan dan pelatihan mengenai metode dan prosedur yang benar, perhatian atau perawatan peralatan kesehatan kerja, bagaimana menggunakan, merawat dan memaksimalkan peralatan $\mathrm{K} 3$, pemakaian pelindung yang sudah ditetapkan. Inspeksi rutin dan teliti oleh pihak pemerintahan dilokasi proyek dan perberlakukan aturan secara tegas serta memberikaan sanksi yang berarti jika terjadi pelanggaran yang keras tentang K3, akan membuat perusahaan berusaha lebih baik lagi dan lebih teliti lagi dalam menerapkan K3.

2. Peningkatan intensif terhadap pekerja di lingkungan proyek untuk memacu kebiasaaan yang aman, misalnya dengan pemberian penghargaan kepada pekerja dalam hal pemakaian APD dan ketatan dalam mematuhi peraturan K3 serta dikenakannya senksi untuk segala macam pelanggaran aturan

\section{UCAPAN TERIMAKASIH}

Penulis mengucapkan terimakasih kepada semua pihak yang telah membantu mewujudkan penelitian ini sehingga kendala-kendala yang dihadapi dapat diatasi.

\section{DAFTAR PUSTAKA}

Victoria, Mintje,(2013) Penerapan sistem Pengendalian Keselamatan dan Kesehatan Kerja pada pelaksanaan konstruksi (studi kasus : Lanjutan pemebangunan fasilitas pelabuhan laut Manado T.A.2012).

Pangkey, Febyana,(2012) Penerapan sistem manajemen kesehatan dan keselamatan kerja (SMK3) pada proyek Konstruksi Di Indonesia.

Indah, Aryani,(2017) Evaluasi penerapan keselamatan dan kesehatan kerja (K3) pada proyek Bangunan Gedung di kabupaten Cibinong.

Dameyanti Sihombing \& D. R. Walsngitan. Pingkan A. K. Pratasis,(2014) Implementasi Keselamatan dan kesehatan kerja (K3) pada proyek di Kota Bitung.

M. Almer, Rikardo \& Hendra taufik,(2015) Tinjauan penerapan sistem manajemen keselamatan dan kesehatan kerja (SMK3) pada proyek pembangunan Hotel Novotel PekanBaru.

I Wayan Jawat,(2017) Pengendalian keselamatan dan kesehatan kerja pada proyek pembangunan Hotel.

Achmat, Ramdahi,(2012) Penerapan sistem manajemen Keselamatan dan kesehatan kerja (SMK3) (Studi pada proyek pembangunan jalan rawa buaya, Cengkareng )

Firman Alimuddin,(2010) Penerapan Sistem manajemen keselamatan dan kesehatan kerja Di RSUP tarakan tahun 2010)

Kaming F, Raharjo, dan Yulianto (2011) komparasi hasil pelaksanaan program keselamatan dan kesehatan kerja (K3) pada proyek konstruksi.

Kurniawan, Yanuar, (2015) Tingkat pelaksanaan sistem manjemen keselamatan dan kesehatan kerja (SMK3) pada proyek konstruksi, studi kasus Di Kota Semarang.

Andini, karina (2012) Analisa Implementasi sistem manajemen keselamatan dan kesehatan kerja. 
